\title{
Sequential Electrodeposition of Platinum-Ruthenium at Boron-Doped Diamond Electrodes for Methanol Oxidation
}

\author{
Ileana González-González, ${ }^{1,2}$ Camille Lorenzo-Medrano, ${ }^{1,2}$ and Carlos R. Cabrera ${ }^{1,2}$ \\ ${ }^{1}$ Department of Chemistry, University of Puerto Rico, Río Piedras Campus, P.O. Box 70377, San Juan, PR 00936-8377, USA \\ ${ }^{2}$ Center for Advanced Nanoscale Materials, University of Puerto Rico, Rio Piedras Campus, P.O. Box 70377, \\ San Juan, PR 00936-8377, USA
}

Correspondence should be addressed to Carlos R. Cabrera, carlos.cabrera2@upr.edu

Received 5 April 2011; Revised 11 July 2011; Accepted 18 July 2011

Academic Editor: Milan M. Jaksic

Copyright (C 2011 Ileana González-González et al. This is an open access article distributed under the Creative Commons Attribution License, which permits unrestricted use, distribution, and reproduction in any medium, provided the original work is properly cited.

\begin{abstract}
Sequential electrodeposition of $\mathrm{Pt}$ and $\mathrm{Ru}$ on boron-doped diamond (BDD) films, in $0.5 \mathrm{M} \mathrm{H}_{2} \mathrm{SO}_{4}$ by cyclic voltammetry, has been prepared. The potential cycling, in the aqueous solutions of the respective metals, was between 0.00 and $1.00 \mathrm{~V}$ versus $\mathrm{Ag} / \mathrm{AgCl}$. The catalyst composites, $\mathrm{Pt}$ and $\mathrm{PtRu}$, deposited on BDD film substrates, were tested for methanol oxidation. The modified diamond surfaces were also characterized by scanning electron microscopy-X-ray fluorescence-energy dispersive spectroscopy, X-ray photoelectron spectroscopy, and Auger electron spectroscopy. The scanning Auger electron spectroscopy mapping showed the ruthenium signal only in areas where platinum was electrodeposited. Ruthenium does not deposit on the oxidized diamond surface of the boron-doped diamond. Particles with $5-10 \%$ of ruthenium with respect to platinum exhibited better performance for methanol oxidation in terms of methanol oxidation peak current and chronoamperometric current stability. The electrogenerated - $\mathrm{OH}$ radicals on BDD may interact with Pt surface, participating in the methanol oxidation as shown in oxidation current and the shift in the peak position. The conductive diamond surface is a good candidate as the support for the platinum electrocatalyst, because it ensures catalytic activity, which compares with the used carbon, and higher stability under severe anodic and cathodic conditions.
\end{abstract}

\section{Introduction}

The direct methanol fuel cells (DMFC) are electrochemical cells that convert chemical energy in electrical energy that can be use to power all kind of appliances. Similar to polymer electrolyte membrane fuel cells (PEMFCs), in the DMFC the anode catalyst draws the hydrogen from the methanol, and both systems use a solid electrolyte, reducing the corrosion of the device and improving the power density. Various catalytic composite systems have been studied, including PtRuOsIr [1], PtRuOs [2], PtMo [3, 4], and PtRu [5, 6]. Electrodes with catalyst nanoparticles have been found to have highly catalytic performance, and the catalytic activity was found to depend on the particle size, the nature of the support, as well the preparation method [7].

One of the subjects of research on high-efficiency fuel cells is how to minimize the electrocatalytic noble metal loading without losing the high catalytic activity. This is achieved by dispersing nanoparticles of the catalytic materials (mainly Pt-based alloys) on high surface area materials used as supports. The supports need to, in addition to having high surface, be stable and conductive. The most commonly used particle support is carbon blacks, these undergo irreversible oxidation at positive potentials, and this is a challenge particularly on the oxygen reduction electrode where they undergo high positive potentials ( $0.7-1.0$ versus NHE), but it can occur in the anode during fuel starvation [8-10]. When the carbon blacks support oxidizes their resistance increase, the electrocatalytic particles become loose, and they lose a high number of reaction sites due to agglomeration [10-14]. The development of advanced support materials that are stable at high potentials, low $\mathrm{pH}$, and relatively elevated temperatures is still the subject of much study [15]. Diamond, carbon nanotubes [16], nanoporous supports and highly ordered carbon materials have been studied in order to improve the stability of the electrodes of the cell. 
Boron-doped diamond (BDD) films exhibit very high chemical and electrochemical stability. The potential range in which high stability exists is greater than $2.5 \mathrm{~V}$, much greater than conventional carbon-based electrode materials such as glassy carbon and carbon blacks. BBD films exhibit very high stability to vigorous chemical and electrochemical treatments $[11,17]$. Diamond films prepared by chemical vapordeposition have been employed in numerous applications due to their unique characteristics. Various studies on metal particle deposition on BDD have been carried out to examine the catalytic properties of the films [18, 19]. This excellent stability provides a rationale for the use of diamond as a support for metal nanoparticles, because various modified surfaces can be confidently used to enhance the bonding to these nanoparticles.

In the present work, we have used the polished borondoped microcrystalline diamond film as a model system, in order to study the deposition of noble metal electrocatalysts and to characterize their morphology and electrocatalytic behavior on the diamond surface. As a first step, we have characterized typical BDD films and then have sequentially electrodeposited platinum and ruthenium particles on the surface. The PtRu modified electrodes were used for methanol oxidation.

\section{Methodology}

2.1. Boron-Doped Diamond Film. BDD films were bought from Element Six, the specifications given by the manufacturer were $10 \mathrm{~mm} \times 10 \mathrm{~mm} \times 1 \mathrm{~mm}$ thickness, polished surface finish grown by chemical vapor deposition with a resistivity $0.038-0.105 \Omega-\mathrm{cm}$, and a doping level of [B] $>10^{20} \mathrm{~cm}^{-3}$. Each diamond film was cleaned by using a solution of aqua-regia, followed by cycling from $-0.8 \mathrm{~V}$ to +1.6 versus $\mathrm{Ag} / \mathrm{AgCl}$ in sulfuric acid $0.5 \mathrm{M}$, and tested as clean sample of boron-doped diamond.

\subsection{Electrochemistry and Platinum-Ruthenium Electrodepo-} sition. All the experiments were performed in an in-house designed electrochemical cell. The boron-doped diamond (BDD) films were used as working electrodes, $\mathrm{Ag} / \mathrm{AgCl}$ as reference electrode, and a $\mathrm{Pt}$ wire as counter electrode, respectively. Sulfuric acid optima (95-98\%, Fisher) was used to prepare a $0.5 \mathrm{M}$ aqueous solution as electrolyte. All the electrochemical measurements were performed using a PARSTAT 2273 potentiostat.

Potassium hexachloroplatinate (IV; 98\%, Sigma-Aldrich) and ruthenium (III) chloride (45-55\%, Sigma-Aldrich), dissolved in $0.5 \mathrm{M} \mathrm{H}_{2} \mathrm{SO}_{4}$, were used as metal precursors for the sequential electrodeposition of $\mathrm{Pt}: \mathrm{Ru}$. Pt deposition was carried out using $\mathrm{K}_{2} \mathrm{PtCl}_{6} 1 \mathrm{mM}$ cycling between $-0.2 \mathrm{~V}$ and $1.0 \mathrm{~V}$ versus $\mathrm{Ag} / \mathrm{AgCl}$ at a scan rate of $500 \mathrm{mVs}^{-1}$. Then the sample was cleaned using cyclic voltammetry between $-0.2 \mathrm{~V}$ and $1.2 \mathrm{~V}$ versus $\mathrm{Ag} / \mathrm{AgCl}$ at a scan rate of $500 \mathrm{mVs}^{-1}$ in $\mathrm{H}_{2} \mathrm{SO}_{4} 0.5 \mathrm{M}$ until the voltammogram of polycrystalline platinum was perfectly reproduced. For the Ru sequential deposition, four different concentrations were used $1 \mathrm{mM}, 0.5 \mathrm{mM}, 0.1 \mathrm{mM}$, and $0.05 \mathrm{mM}$ of $\mathrm{RuCl}_{3}$.

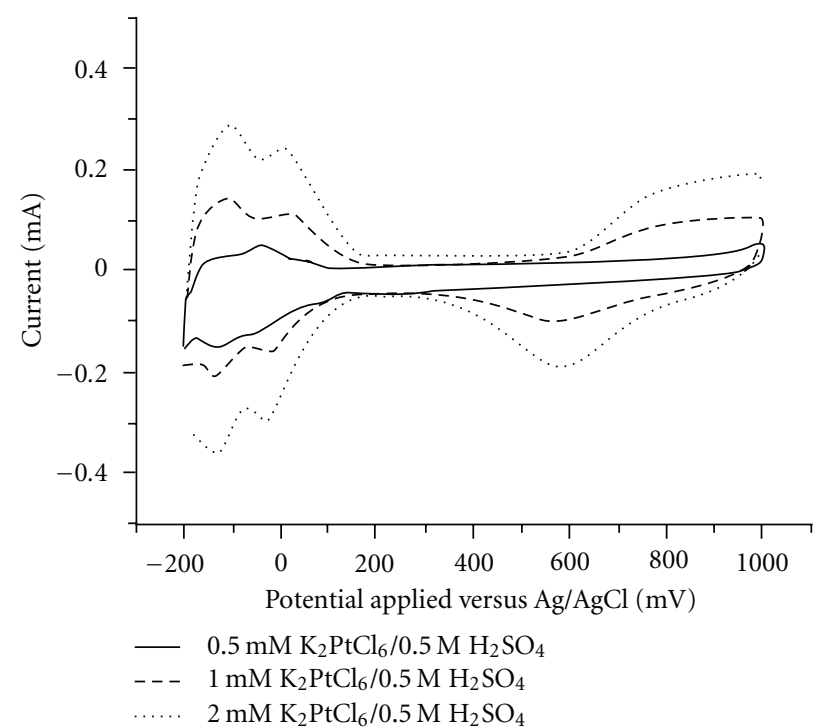

Figure 1: Cyclic voltammogram of Pt-BDD films at $50 \mathrm{~V} / \mathrm{s}$ in a $\mathrm{N}_{2}$ spurged $0.5 \mathrm{M} \mathrm{H}_{2} \mathrm{SO}_{4}$ solution. Pt particles deposited by cyclic voltammetry $-0.2 \mathrm{~V}$ and $1.0 \mathrm{~V}$ versus $\mathrm{Ag} / \mathrm{AgCl}$ at $\mathrm{Pt} 500 \mathrm{mVs}^{-1}$ for (a) 0.5 , (b) 1.0 , and (c) $2.0, x \mathrm{mM} \mathrm{K}_{2} \mathrm{PtCl}_{6}$.

All the electrodepositions were carried out by cycling the potential between $-0.2 \mathrm{~V}$ and $0.8 \mathrm{~V}$ versus $\mathrm{Ag} / \mathrm{AgCl}$ at a scan rate of $500 \mathrm{mVs}^{-1}$. Finally, methanol (99\%, Sigma-Aldrich) $1 \mathrm{M}$ in $\mathrm{H}_{2} \mathrm{SO}_{4} 0.5 \mathrm{M}$ was oxidized between $-0.2 \mathrm{~V}$ and $0.8 \mathrm{~V}$ versus $\mathrm{Ag} / \mathrm{AgCl}$ at a scan rate $50 \mathrm{mVs}^{-1}$. Chronoamperometry measurements were performed at $0.35 \mathrm{~V}$ versus $\mathrm{Ag} / \mathrm{AgCl}$. All electrochemical measurements were done at room temperature.

2.3. Particle Characterization. The various electrodeposited catalysts were characterized by scanning electron microscopy-X-ray energy-dispersive analysis (SEM/EDS), X-ray diffraction, and cyclic voltammetry. For the SEM micrographs a JEOL 5800LV microscope was used at $15 \mathrm{kV}$. Platinum particle size distribution measurements were performed using the UTHSCSA Image Tool program [20], in which the SEM images were imported and the sizes of the white pixels were measured. This was done in the manual mode to avoid incorrect identification of the particles.

$\mathrm{X}$-ray diffraction analyses were performed using a SIEMENS D5000 X-ray diffractometer using a $\mathrm{Cu} \mathrm{K} \alpha$ polychromatic X-ray source. The Raman spectra were obtained with an ISA-JY T64000 spectrometer. The measurements were performed in the backscattering configuration on a spot of about $3 \mathrm{~mm}$ in diameter illuminated with an $\mathrm{Ar}^{+}$laser $(514.5 \mathrm{~nm}, 10-\mathrm{mW})$.

The XPS analysis data was obtained using a PHI 5600ci spectrometer with an $\mathrm{Al} \mathrm{Ka} \mathrm{X-ray} \mathrm{source} \mathrm{at} 15 \mathrm{kV}$ and $350 \mathrm{~W}$. Binding energies were corrected to the $\mathrm{C} 1 \mathrm{~s} \mathrm{sp} 3$ signal at $284.5 \mathrm{eV}$ [21]. Auger electron spectroscopy measurements were done in a Perking Elmer PHI 660 Scanning Auger Multiprobe at $10 \mathrm{keV}$. 


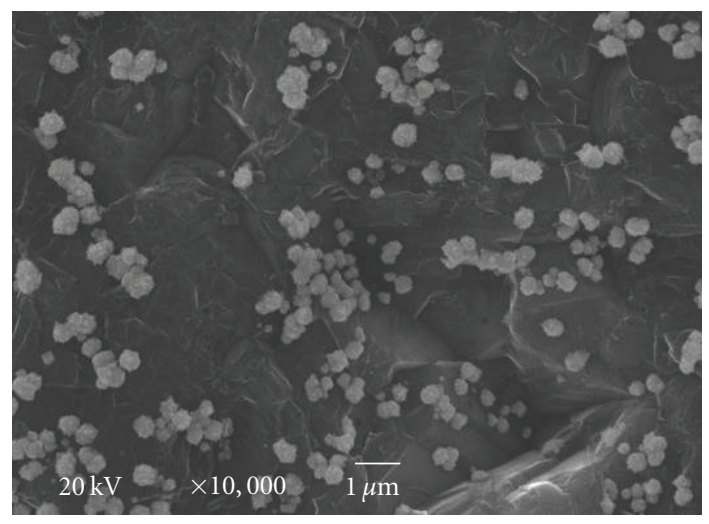

(a)

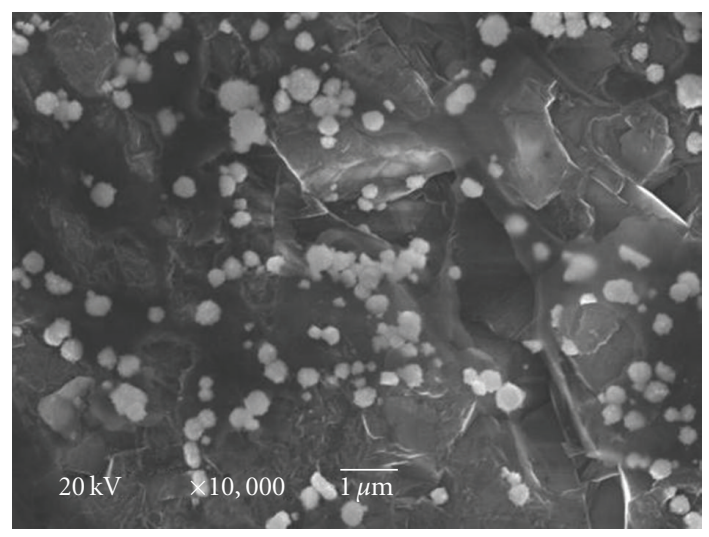

(c)

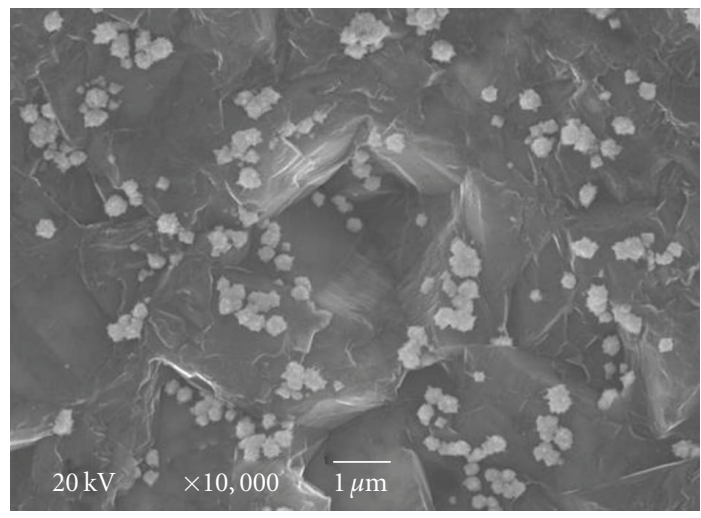

(b)

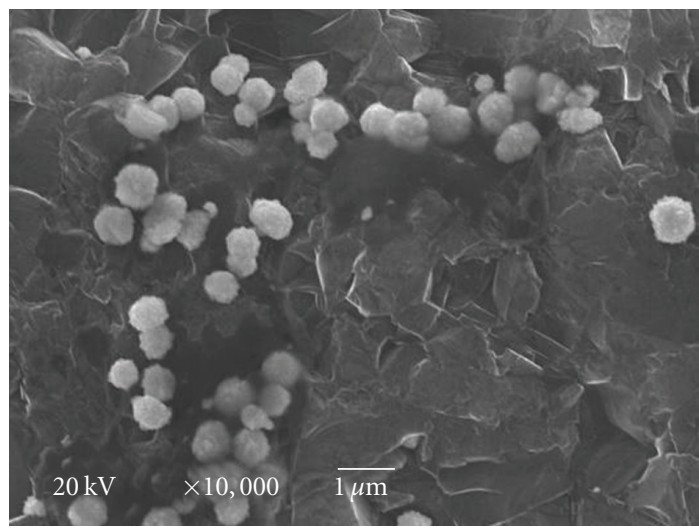

(d)

FIGURE 2: SEM images of Pt-Ru sequential deposition on BDD films obtained at $20 \mathrm{kV}$ and magnification of 10,000x, by cyclic voltammetry, between $-0.2 \mathrm{~V}$ and $1.0 \mathrm{~V}$ versus $\mathrm{Ag} / \mathrm{AgCl}$ for $\mathrm{Pt}$ and $-0.2 \mathrm{~V}$ and $0.8 \mathrm{~V}$ versus $\mathrm{Ag} / \mathrm{AgCl}$ for Ru at sweep rate $500 \mathrm{mVs}^{-1}$ for (a) $1: 1$, (b) $1: 0.5$, (c) $1: 0.1$, and (d) $1: 0.05,1 \mathrm{mM} \mathrm{K}_{2} \mathrm{PtCl}_{6}$ and $x \mathrm{mM} \mathrm{RuCl}_{3}$ solution.

\section{Results and Discussion}

3.1. Boron-Doped Diamond Film Characterization. The BDD films used were of high quality, including predominantly (111-) type and (100-) type grains and facets, as confirmed by X-ray diffraction analysis, which has a peak pattern characteristic for diamond crystals. The first peak, appeared at $44.1^{\circ}$, due to (111) plane, and a second peak, at $75.3^{\circ}$, was characteristic of the (220) plane. The (220) peak were more intense than the (111) peak; this is because the growth process occurred preferentially in the (220) plane. The third peak, at $91.6^{\circ}$, was assigned to the (311) plane.

As a standard characterization of the BDD films bought, Raman spectral analysis was done. From the Raman spectra, the peak at $1332 \mathrm{~cm}^{-1}$ confirmed the presence of $\mathrm{sp} 3$ carbons, as expected for diamond materials. A small broad peak in the $1598 \mathrm{~cm}^{-1}$ region indicated the presence of $\mathrm{sp} 2$ carbon impurities. The films were of good quality, although sp2 carbon contamination was present, the width of the $1332 \mathrm{~cm}^{-1}$ full width at half-maximum diamond line was $4.7-7.1 \mathrm{~cm}^{-1}$, compared with $2.6 \mathrm{~cm}^{-1}$ and $10.5 \mathrm{~cm}^{-1}$ for crystals with best and poorest crystallinity, respectively [22]. The broad peak of the $500 \mathrm{~cm}^{-1}$ was used to calculate the boron concentration using the maximum of the Lorentzian component, $5.6 \times 10^{19}-3.0 \times 10^{20} \mathrm{~B} \mathrm{~cm}^{-3}$ in diamond [23].

The cyclic voltammetry measured in $0.5 \mathrm{M} \mathrm{H}_{2} \mathrm{SO}_{4}$ showed a wide potential range in which there was relatively small background current, close to $3 \mathrm{~V}$. This contrasts with gold, platinum, glassy carbon, and other commonly used electrodes and is due to the lack of catalytic activity for the hydrogen and oxygen electrolytic gas generation reactions, together with the slow tendency to undergo electrochemically induced surface oxidation [24].

\subsection{Platinum Particle Deposition}

3.2.1.Particle Analysis. Platinum electrodeposition was carried out by sweeping the potential back and forth (cyclic voltammetry) between -0.2 and $1.0 \mathrm{~V}$ in a $\mathrm{K}_{2} \mathrm{PtCl}_{6} / 0.5 \mathrm{M} \mathrm{H}_{2} \mathrm{SO}_{4}$ solution at $500 \mathrm{mV} / \mathrm{s}$, where the platinum concentration was varied from $0.5 \mathrm{mM}$ to $2.0 \mathrm{mM}$. The particles were observed by scanning electron microscopy (SEM), and their elemental composition was verified by X-ray fluorescence-energy dispersive spectroscopy (EDS; not shown). The average size of the Pt particles was approximately $574 \mathrm{~nm} \pm 200 \mathrm{~nm}$, 


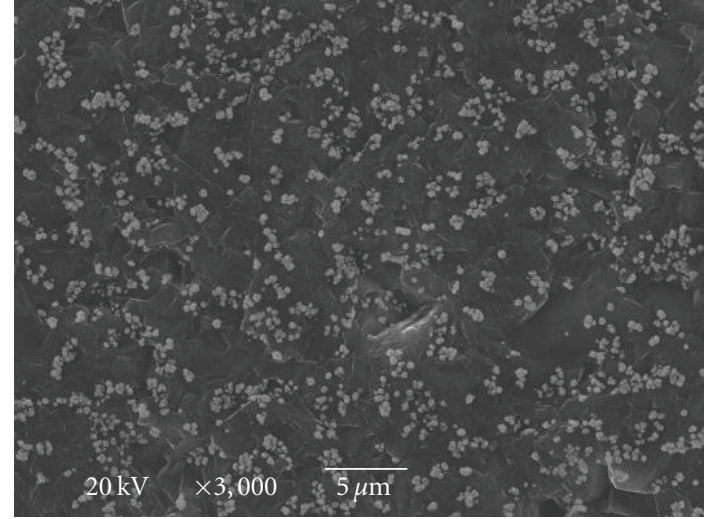

(a)

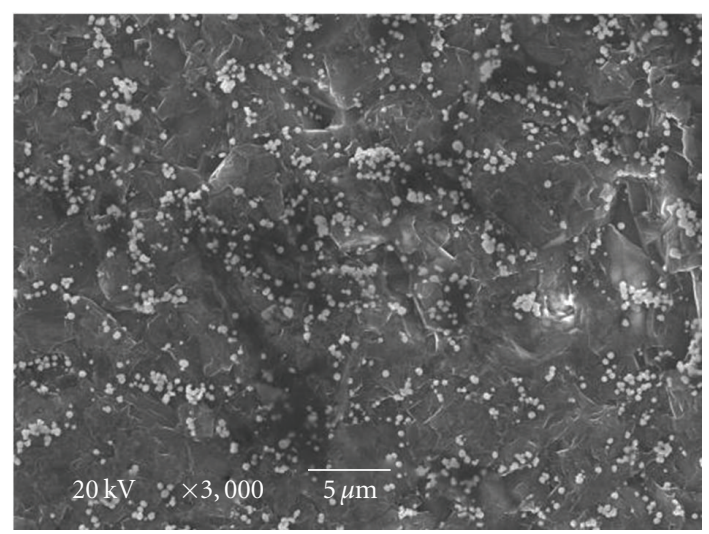

(c)

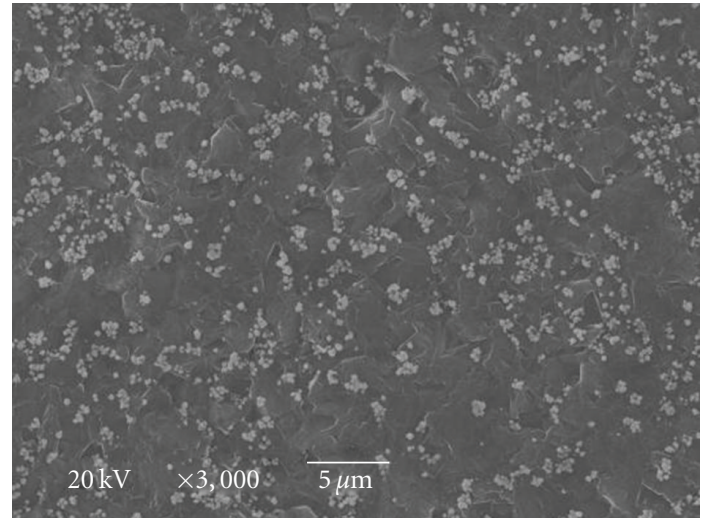

(b)

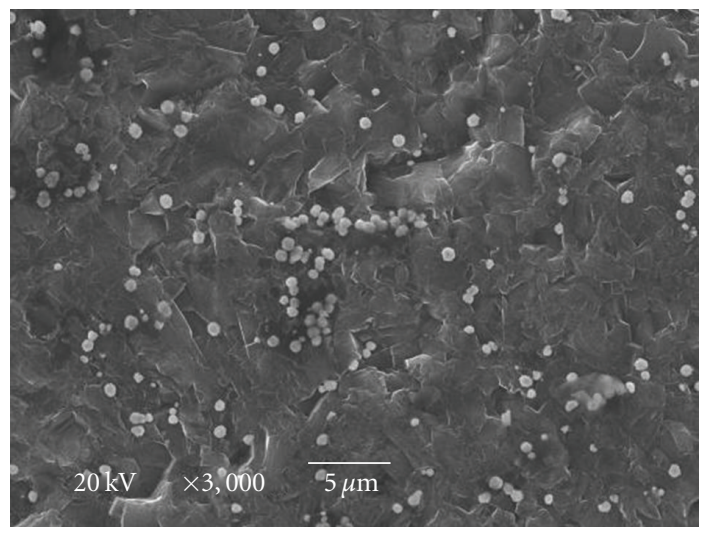

(d)

Figure 3: Scanning electron microscopy (SEM) images of Pt-Ru sequential deposition on BDD films obtained at $20 \mathrm{kV}$ and magnification of 3,000x, by cyclic voltammetry, between $-0.2 \mathrm{~V}$ and $1.0 \mathrm{~V}$ versus $\mathrm{Ag} / \mathrm{AgCl}$ for $\mathrm{Pt}$ and $-0.2 \mathrm{~V}$ and $0.8 \mathrm{~V}$ versus $\mathrm{Ag} / \mathrm{AgCl}$ for $\mathrm{Ru}$ at sweep rate $500 \mathrm{mVs}^{-1}$ for (a) $1: 1$, (b) $1: 0.5$, (c) $1: 0.1$, and (d) $1: 0.05,1 \mathrm{mM} \mathrm{K}_{2} \mathrm{PtCl}_{6}$ and $x \mathrm{mM} \mathrm{RuCl}_{3}$ solution.

the size of the platinum particles did not change with the platinum solution concentration used during the deposition voltammetry. The particle density was approximately $1.01 \times$ $10^{7}, 1.25 \times 10^{7}$, and $4.27 \times 10^{7}$ particles- $\mathrm{cm}^{-2}$ for $0.5 \mathrm{mM}$, $1.0 \mathrm{mM}$, and $2.0 \mathrm{mM}$, respectively. This value compares with the values obtained by Enea et al. in the $200-800 \mathrm{~nm}$ range [25], those of Montilla et al. in the 150 to $700 \mathrm{~nm}$ range [26] and with those obtained by Bennett et al. prepared by galvanostatic deposition (20-45 nm, depending on the type of diamond film) [27], for example, $46 \pm 27 \mathrm{~nm}$ diameter and $1.1 \times 10^{9}$ particles- $\mathrm{cm}^{-2}$.

3.2.2. Electrochemical Characterization. Figure 1 shows the typical cyclic voltammogram for the platinum particles deposited on the boron diamond film surface for all the concentrations. Cyclic voltammograms of the platinum particledecorated BDD film were obtained after cleaning cycles were completed, it showed the characteristic current features for platinum, hydrogen adsorption and desorption (100 to $-250 \mathrm{mV}$ ), Pt oxide formation $(700-1000 \mathrm{mV}$ ), and $\mathrm{Pt}$ oxide reduction $(550 \mathrm{mV})$ [28]. The electrochemically active surface area of the electrode was estimated by integrating the anodic current peak for hydrogen desorption obtained during the forward sweep $(-0.2 \mathrm{~V}$ to $0.1 \mathrm{~V}$ versus $\mathrm{Ag} / \mathrm{AgCl})$ [29]. As shown in Figure 2, the surface area of the platinum particles increases with higher concentration solution used during the depositions cycles; this is because of higher particle distribution, as the particle size remains very close for all the samples. As the concentration of the platinum solution increases the amount of particles formed increases. This tells us that, as expected, the nucleation of a new particle is easier with the proximity of the specie to be reduced to the surface to be modified. For the Pt particles deposited onto bare BDD surface, the Pt seeds firstly appeared and after that grew into large Pt particles. In such cases, the growth process dominates, and finally smaller particles could be formed. These particles that we believed are formed could not be observed in our SEM facilities. Cycle voltammetric analysis for methanol oxidation of the Pt decorated borondoped diamond films exhibited the characteristic features of methanol oxidation on pure platinum.

\subsection{Sequential Platinum-Ruthenium Particle Deposition}

3.3.1. Particle Analysis. Platinum and ruthenium were electrochemically deposited sequentially by means of cyclic 


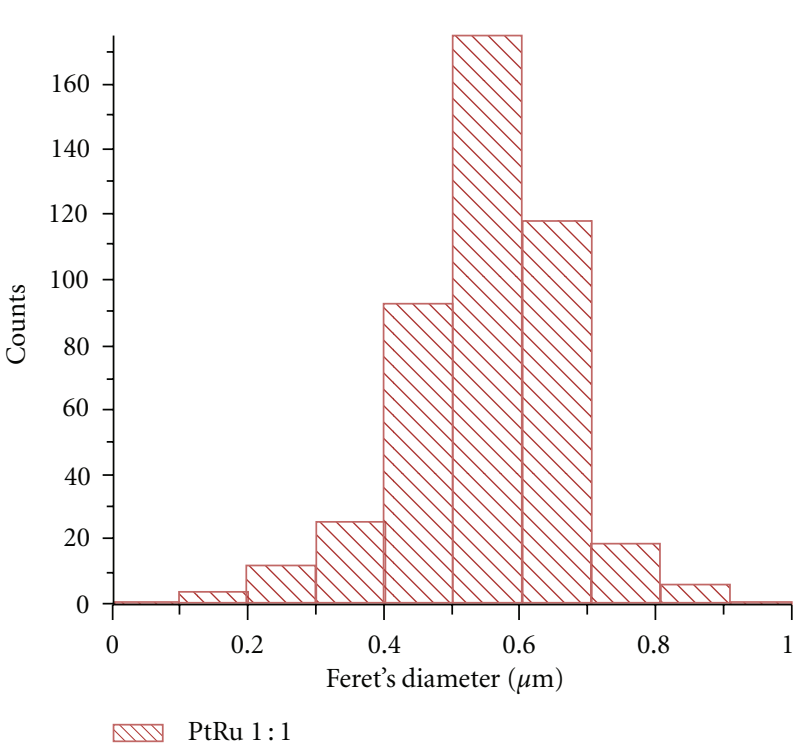

(a)

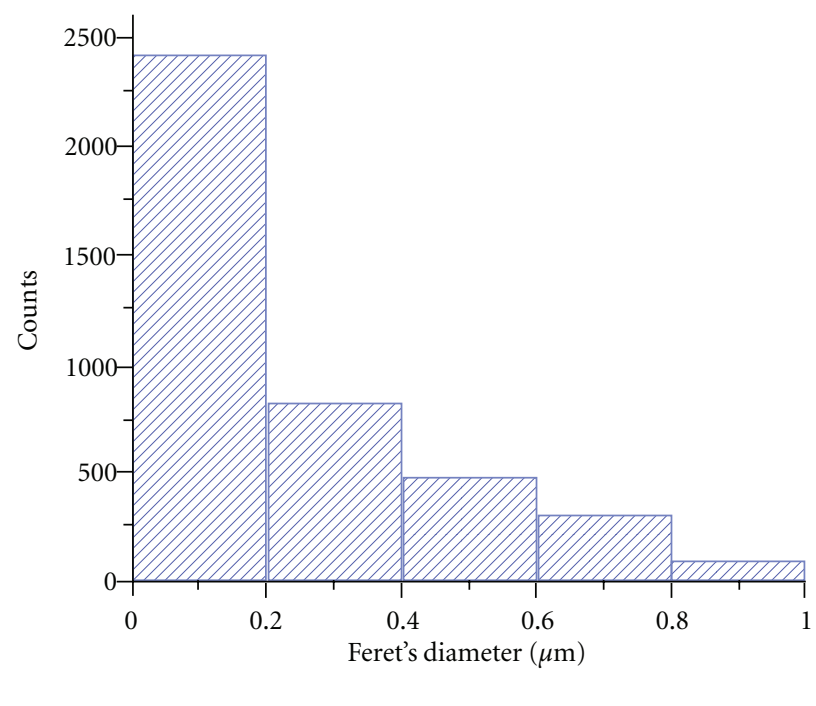

DI7 PtRu $1: 0.1$

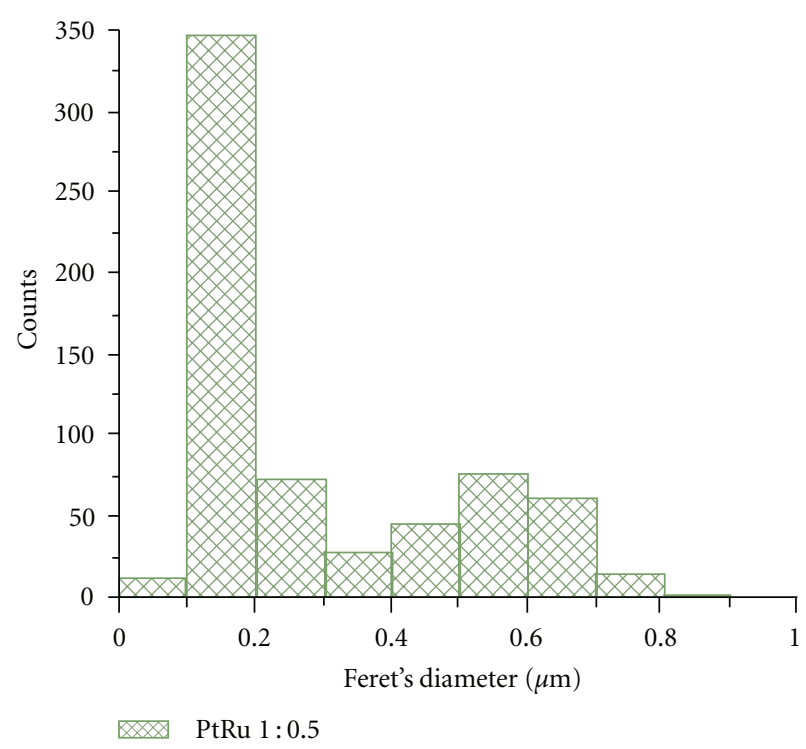

(b)

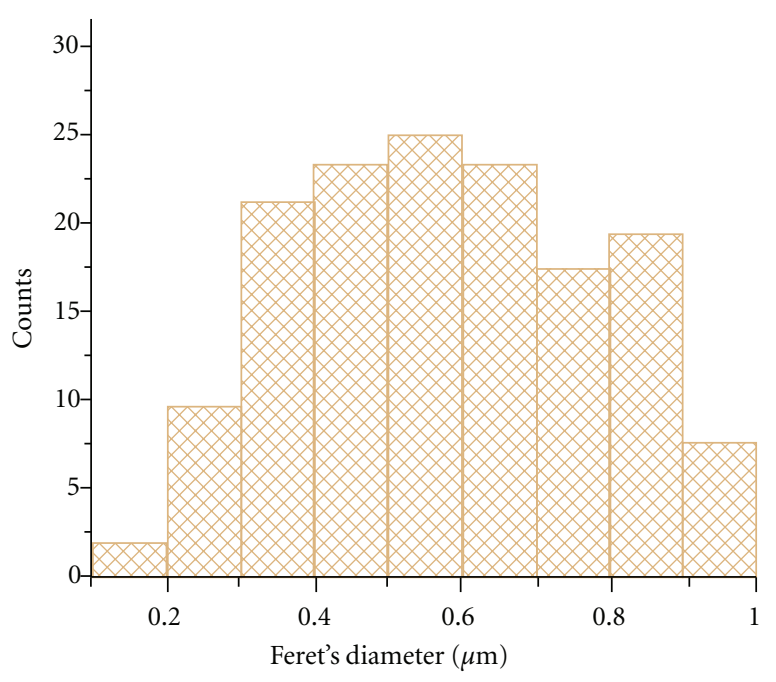

PtRu 1:0.05

(c)

(d)

FIgURE 4: Histogram for particle size analysis of Pt-Ru sequential deposition on boron-doped diamond electrodes obtained at $20 \mathrm{kV}$ and magnification of 3,000x, by cyclic voltammetry, between $-0.2 \mathrm{~V}$ and $1.0 \mathrm{~V}$ versus $\mathrm{Ag} / \mathrm{AgCl}$ for $\mathrm{Pt}$ and $-0.2 \mathrm{~V}$ and $0.8 \mathrm{~V}$ versus $\mathrm{Ag} / \mathrm{AgCl}$ for $\mathrm{Ru}$ at sweep rate $500 \mathrm{mVs}^{-1}$ for (a) $1: 1$, (b) $1: 0.5$, (c) $1: 0.1$, and (d) $1: 0.05,1 \mathrm{mM} \mathrm{K}_{2} \mathrm{PtCl}_{6}$ and $x \mathrm{mM} \mathrm{RuCl}_{3}$ solution.

voltammetry, potential sweep between 0.2 and $1.0 \mathrm{~V}$ at $50 \mathrm{mV}$ s in $1 \mathrm{mM} \mathrm{K}_{2} \mathrm{PtCl}_{6} / 0.5 \mathrm{M} \mathrm{H}_{2} \mathrm{SO}_{4}$ and $0.05,0.1,0.5$, and $1 \mathrm{mM} \mathrm{RuCl} 3 / 0.5 \mathrm{M} \mathrm{H}_{2} \mathrm{SO}_{4}$ solutions. The particles were observed by SEM, EDS, and Auger electron spectroscopy were used to verify their composition.

The range particle size was approximately 100 $800 \mathrm{~nm}$ for Pt-Ru with particle density of (a) $2.32 \times$ $10^{8}$ particles $/ \mathrm{cm}^{2}$, (b) $2.02 \times 10^{8}$ particles $/ \mathrm{cm}^{2}$, (c) $1.86 \times$ $10^{8}$ particles $/ \mathrm{cm}^{2}$ and (d) $5.12 \times 10^{7}$ particles $/ \mathrm{cm}^{2}$. The particles were distributed in a nonhomogenous way throughout the surface of the diamond film, as can be seen in Figures 2 and 3 for all the samples. We see in the micrographs the agglomeration of particles for all the depositions, contrasting with the results of Montilla et al. [26] and Bennett et al. [27]. We believe this nonhomogenous distribution of the particles is due to the heterogeneous conductivity of diamond films that have been previously observed on doping levels of $10^{20} \mathrm{~B} / \mathrm{cm}^{3}$ and below [30]. Histograms for the particle size distribution are shown in Figure 4, modal sizes are $525 \mathrm{~nm}$, $150 \mathrm{~nm}, 125 \mathrm{~nm}$, and $625 \mathrm{~nm}$, for deposition done using solutions $0.05,0.1,0.5$, and $1 \mathrm{mM} \mathrm{RuCl} / 0.5 \mathrm{M} \mathrm{H}_{2} \mathrm{SO}_{4}$, respectively.

The chemical composition of the particles was verified with several techniques. Auger spectroscopy and EDS verified the elemental composition of the PtRu particles decorated boron-doped diamond films. 


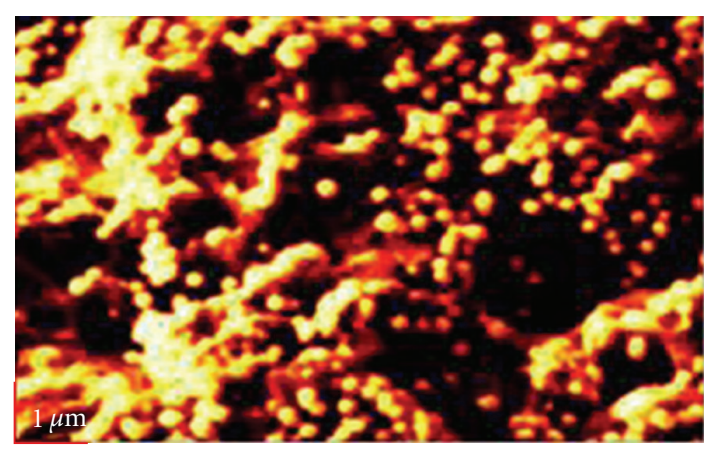

(a)

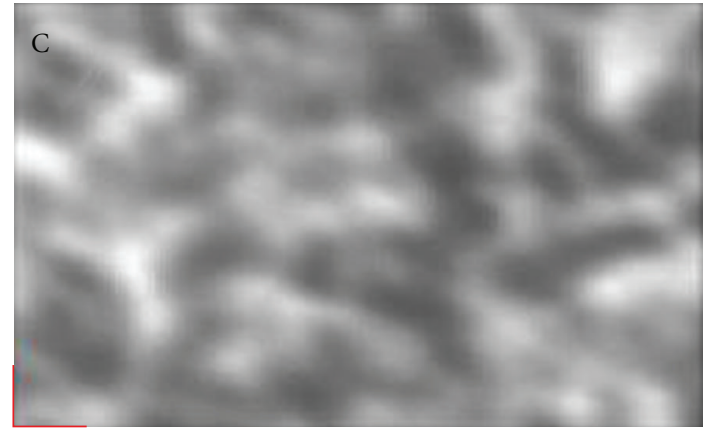

(b)

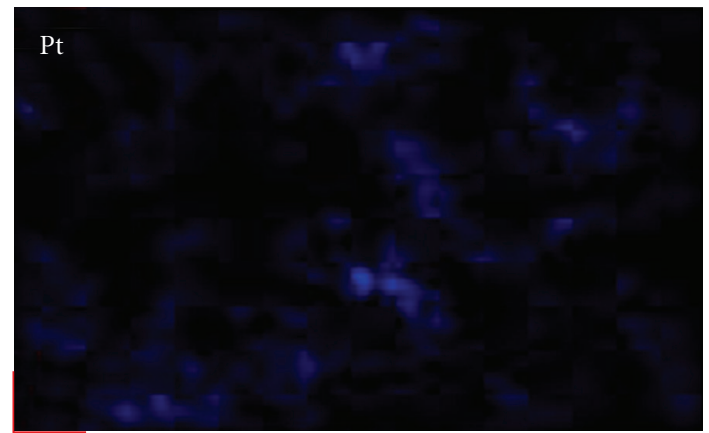

(d)

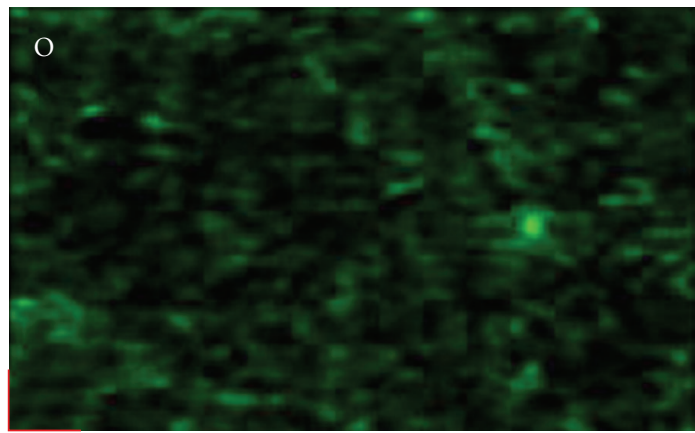

(c)

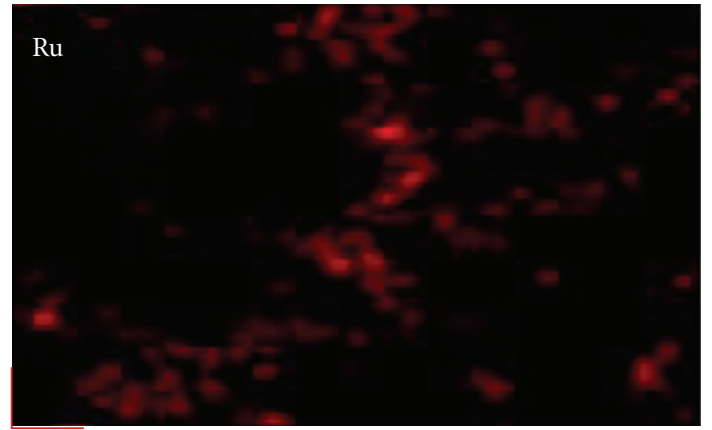

(e)

FIgure 5: Scanning electron microscopy and scanning Auger electron spectroscopy mapping images for the C KLL, O KLL, Pt MNN, and $\mathrm{Ru}$ LMM on Pt-Ru particle deposited sequentially on BDD films using $1.0 \mathrm{mM} \mathrm{K}_{2} \mathrm{PtCl}_{6}$ and $1.0 \mathrm{mM} \mathrm{RuCl}_{3}$ solution.

Figure 5 shows the SEM and Auger electron spectroscopy mapping for signals of the elements: carbon, oxygen, platinum, and ruthenium. Oxygen mapping shows that it is present in the entire surface, boron-doped diamond films surface is oxidized due to the cleaning process and pretreatment done to the films when received. The platinum mapping shows where the platinum particles are deposited on the surface, and the ruthenium signal is only detected in areas where platinum is deposited. Ruthenium, as previously published for other carbon supports, was not deposited on the oxidized diamond surface of the boron-doped diamond $[6]$.

Further chemical characterization was done by highresolution XPS spectra for the binding energy regions of $\mathrm{C}$ 1s, O 1s, Pt 4f, and Ru 3p (Figures 6 and 7). The C1s region has been fitted to three binding energy peaks: one main peak at $284.5 \mathrm{eV}$ and two additional peaks $+1.0 \mathrm{eV}$ and $+3.7 \mathrm{eV}$ higher binding energies. The peak at $+1.0 \mathrm{eV}$, attributed to $\mathrm{C}-\mathrm{O}$, is correlated $[31,32]$ to $\mathrm{C}-\mathrm{OH}$ from $(111)$ facets and $\mathrm{C}-$ $\mathrm{O}-\mathrm{C}$ from (110) facets. The peak $+3.7 \mathrm{eV}$ can be attributed to $\mathrm{C}=\mathrm{O}$ from the (110) facet [33]. Oxygen 1s region shows two main peaks, one attributable to $\mathrm{C}-\mathrm{O}$ interaction and the second to metal oxides, from both metals, $\mathrm{Pt}$ and Ru.

The high-resolution X-ray photoelectron spectrum shows the binding energy peak of $\mathrm{Pt}^{0} 4 \mathrm{f}_{5 / 2}$ and $\mathrm{Pt}^{0} 4 \mathrm{f}_{7 / 2}$, and with an increase of $+1.2 \mathrm{eV}$ in the binding energy, the signal for platinum dioxide which consist of $20 \%$ relative to the $\mathrm{Pt}^{0}$ signal. Ruthenium $3 \mathrm{p}_{1 / 2}$ region shows two main peaks, ruthenium in its reduced form and ruthenium oxide.

3.3.2. Electrochemical Characterization. The catalytic activity of the electrodeposited metal particles was tested by cyclic 


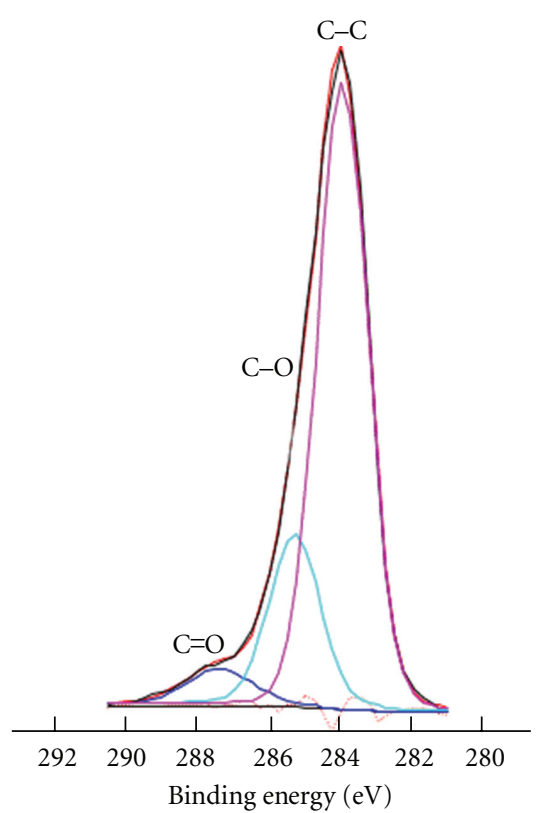

Figure 6: High-resolutions X-ray photoelectron spectra of the $\mathrm{Pt}$ particle decorated boron-doped diamond film. C 1s binding energy region.

voltammetry (see Figure 8(a)). All the cyclic voltammograms for the electrooxidation of $1 \mathrm{M} \mathrm{CH}_{3} \mathrm{OH}$ in $0.5 \mathrm{H}_{2} \mathrm{SO}_{4}$ were performed between $-0.2 \mathrm{~V}$ and $0.8 \mathrm{~V}$ versus $\mathrm{Ag} / \mathrm{AgCl}$ at a sweep rate of $50 \mathrm{mVs}^{-1}$. The maximum current densities for methanol oxidation were in the range of $190-101 \mathrm{~mA} / \mathrm{cm}^{2}$ and $176-78 \mathrm{~mA} / \mathrm{cm}^{2}$, for the Pt-Ru particles deposited on diamond. These results were obtained after the peak currents stabilized after several potential cycles. Thereafter, the peak currents were stable, at least up to 25 total cycles, with no significant loss in activity; only during the first reverse scan we observed smaller currents.

Of greater importance, however, for the fuel cell catalysis is the potential range in which significant anodic current begins to be observed, that is, the oxidation onset potential. Although an arbitrary criterion must be established for this, for example, a given minimum current density, if we take a value of $10 \mathrm{~mA} / \mathrm{cm}^{2}$, the onset potentials were in the range of 332-369 mV versus $\mathrm{Ag} / \mathrm{AgCl}$, for $\mathrm{Pt}-\mathrm{Ru}$ particles deposited on diamond film surface [34]. The fact that Pt-Ru exhibited a lower onset than Pt is certainly expected on the basis of previous literature $[5,35,36]$.

As observed in Figure 8, the reverse current peaks for the oxidation from the platinum surfaces does not correspond to the half the current of the methanol oxidation peak, this observation is consistent with Siné and Chomninellis [37]. This behavior can be explained by the fact that electrogenerated hydroxyl radicals $\mathrm{HO}^{\bullet}$ that are generated on the boron-doped diamond surface at lower $\mathrm{pH}$ electrolytes [38] interact with Pt surface and the organic compounds. Depending on the potential applied this specie can intervene on the oxidation of organic compounds. In the region of water stability, the oxidation of methanol would occur only involving direct electron transfer. Methanol oxidation can

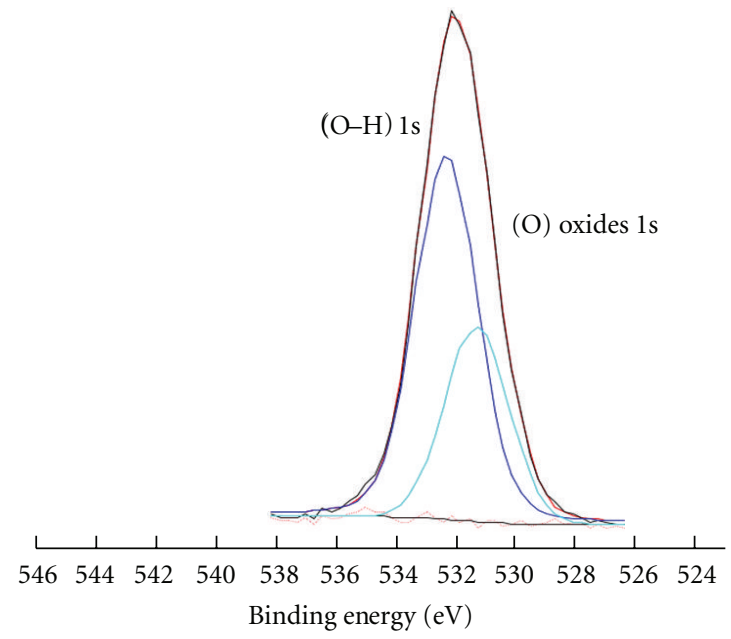

(a)

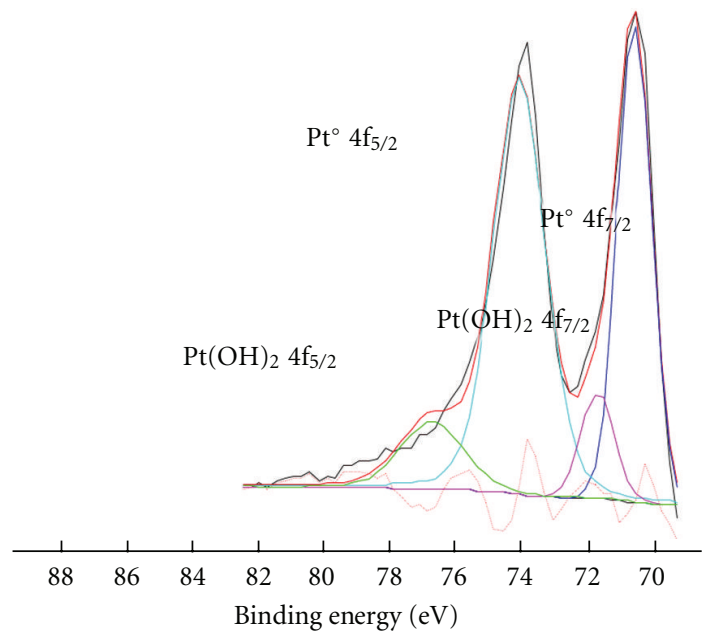

(b)

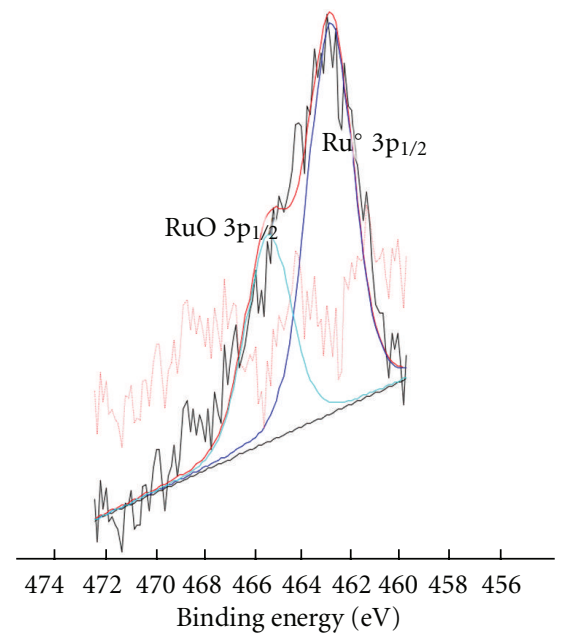

(c)

Figure 7: High-resolutions $\mathrm{X}$ ray photoelectron spectra of the $\mathrm{Pt}$ particle decorated boron-doped diamond film. (b) Pt 4 f region (c) $\mathrm{Ru} 3 \mathrm{p}_{1 / 2}$ energy region (a) $\mathrm{O} 1$ s region. 


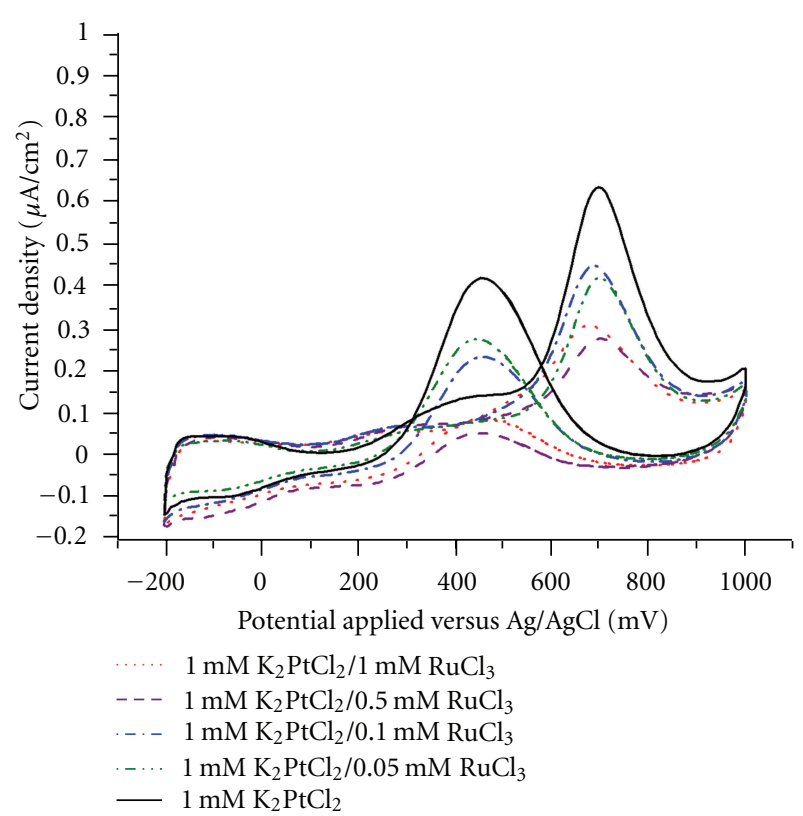

(a)

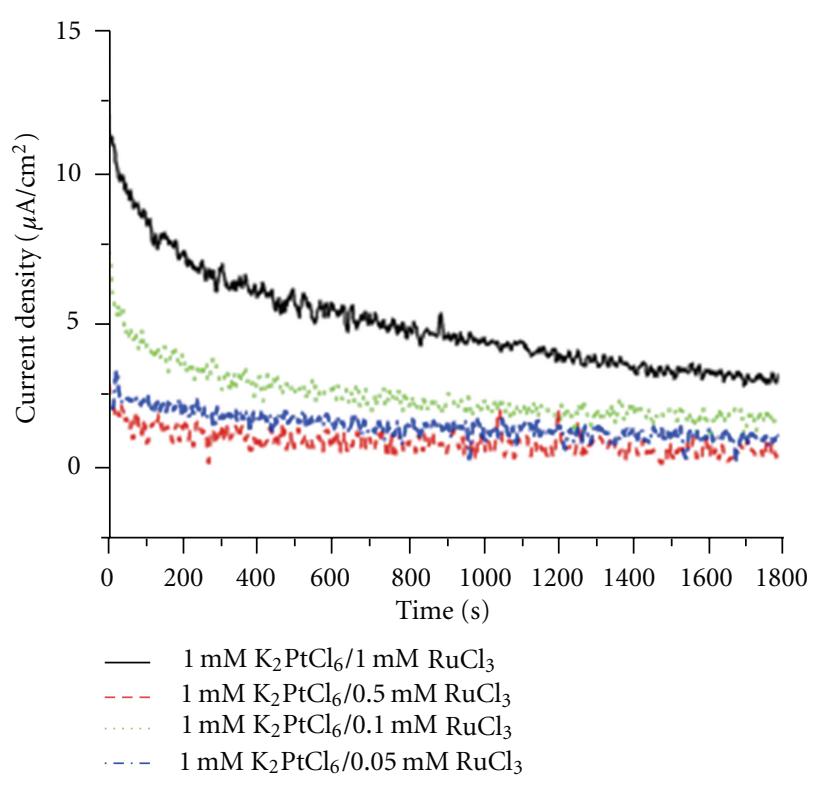

(b)

Figure 8: Cyclic voltammetry on $0.5 \mathrm{M} \mathrm{CH} \mathrm{CH}_{3} \mathrm{OH} / 0.5 \mathrm{M} \mathrm{H}_{2} \mathrm{SO}_{4} \mathrm{Pt}$ particles deposited on boron-doped diamond films by cyclic voltammetry. (a) Chronoamperometry at $350 \mathrm{mV}$ versus $\mathrm{Ag} / \mathrm{AgCl}$ at $24^{\circ} \mathrm{C}$ of Pt particles deposited on boron-doped diamond films by cyclic voltammetry on $0.5 \mathrm{M} \mathrm{CH}_{3} \mathrm{OH} / 0.5 \mathrm{M} \mathrm{H}_{2} \mathrm{SO}_{4}$ (b).

also occur by indirect oxidation, caused by a sequence of chemical and electrochemical steps initiated by the hydroxyl radicals [39].

Also the oxidized surface of diamond that possesses hydroxy $(-\mathrm{OH})$ groups may be involved on the water activation on the platinum surface. Desai and Neurock showed that the presence of surface hydroxyl groups adsorbed to $\mathrm{Ru}$ can induce water to adsorb and activate at neighboring $\mathrm{Pt}$ sites [40]. This water activation could also be enhanced on the oxidized diamond surface (111).

Chronoamperometry was performed at $0.350 \mathrm{~V}$ versus $\mathrm{Ag} / \mathrm{AgCl}$ for all the electrodeposited particles for $1800 \mathrm{~s}$, Figures 8(b) and 9. The samples with greater current loss were the ones without ruthenium, as expected, because of the carbon monoxide poisoning of the platinum surface. For the platinum-ruthenium particles the particles with better current stability were the ones with small quantities of ruthenium. It appears that in particles with greater amounts of $20 \%$ of ruthenium sequentially deposited the ruthenium covers the platinum and the catalytic property of the particle is lost. Lesser positive methanol oxidation onsets were obtained for samples deposited with 0.1 and $1 \mathrm{mM}$ $\mathrm{RuCl}_{3} / 0.5 \mathrm{M} \mathrm{H}_{2} \mathrm{SO}_{4}$, but in terms of current density stability the sample prepared with $0.1 \mathrm{mM} \mathrm{RuCl}_{3} / 0.5 \mathrm{M} \mathrm{H}_{2} \mathrm{SO}_{4}$ had better performance, which is the equivalent to $10 \% \mathrm{Ru} ; 90 \%$ Pt. Current density for Ru $1 \mathrm{mM}$ in series $2(\bullet)$ was taken out of consideration by the $q$-test with $99 \%$ confidence level that is it an outlier.

It is accepted that PtRu is the most promising bimetallic catalyst for methanol oxidation. Its superior activity has been observed for different PtRu materials, such as alloys, codeposits, sequential electrodeposits, and Ru adsorbed on Pt-single-crystal and on Pt carbon-supported electrodes. We have seen that the potential cycling technique yields results that are similar to those of the pulsed galvanostatic technique for platinum itself. For platinum-ruthenium, it is expected that further improvements can be made in reaching higher dispersion, although it has been reported that the dispersion of particles on diamond films is low [41].

\section{Conclusion}

In this work we have examined the possibility of the use of boron-doped diamond as the support for electrocatalyst particles in a fuel cell. The electrochemical behavior of oxidized boron-doped diamond (BDD) films in $0.5 \mathrm{M} \mathrm{H}_{2} \mathrm{SO}_{4}$ using cyclic voltammetry showed a very wide electrochemical window. Platinum particles deposited a different platinum concentrations did not showed a different particle size; although it did show a difference in the particle distribution. $\mathrm{Pt}$ and Pt-Ru particles were deposited on BDD film substrate; the modified diamond surfaces were also characterized by SEM/EDS, XPS, and Auger. High-resolution XPS peak fitting showed that the BDD films were oxidized with $\mathrm{C}-\mathrm{O}, \mathrm{C}-$ $\mathrm{OH}$, and $\mathrm{C}-\mathrm{O}-\mathrm{C}$. Auger electron spectroscopy mapping showed that a complete oxidized surface of diamond and that ruthenium does not deposit on the oxidized diamond surface of the boron-doped diamond. Particles with 5-10\% of ruthenium with respect to platinum exhibited better performance for methanol oxidation in terms of methanol oxidation peak current and current stability. Particles with greater amounts of $20 \%$ of ruthenium sequentially deposited the ruthenium covers the platinum, and the catalytic property of the particle is lost. In the case of cyclic voltammogram for methanol oxidation, a current for the reverse peak is higher than what it is usually observed on carbon supports, a possible explanation is that the electrogenerated hydroxyl 


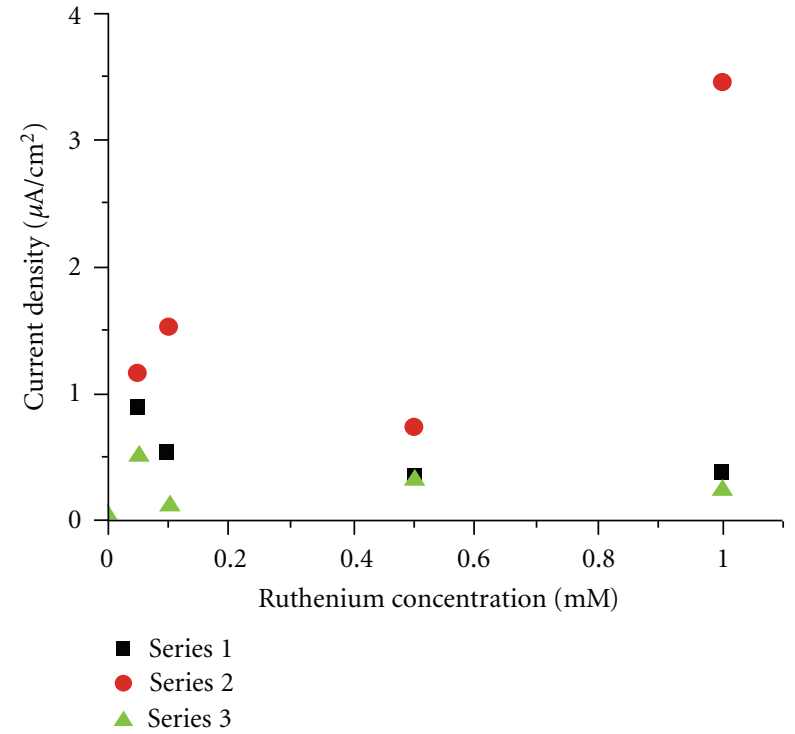

Figure 9: Current at the final point of the chronoamperometry at $350 \mathrm{mV}$ versus $\mathrm{Ag} / \mathrm{AgCl}$ at $24^{\circ} \mathrm{C}$ of $\mathrm{Pt}$ particles deposited on borondoped diamond films.

radical on BDD may interact with Pt surface, participating in the methanol oxidation as showed in the oxidation current and the shift in the peak position.

\section{Acknowledgments}

This paper was supported in part by NASA Grant no. NASANNX08BA48A. I. González-González and C. LorenzoMedrano gratefully acknowledge support from Center for Advanced Nanoscale Materials and Research Initiative Scientific Enhancement. The authors also thank the UPR Materials Characterization Center for all their help with the surface characterization measurements.

\section{References}

[1] E. Reddington, A. Sapienza, B. Gurau et al., "Combinatorial electrochemistry: a highly parallel, optical screening method for discovery of better electrocatalysts," Science, vol. 280, no. 5370, pp. 1735-1737, 1998.

[2] L. Kevin, R. Liu, C. Pu et al., "Methanol oxidation on singlephase Pt-Ru-Os ternary alloys," Journal of the Electrochemical Society, vol. 144, no. 5, pp. 1543-1548, 1997.

[3] H. Zhang, Y. Wang, E. R. Fachini, and C. R. Cabrera, "Electrochemically codeposited platinum/molybdenum oxide electrode for catalytic oxidation of methanol in acid solution," Electrochemical and Solid-State Letters, vol. 2, no. 9, pp. 437439, 1999.

[4] S. Mukerjee, S. J. Lee, E. A. Ticianelli et al., "Investigation of enhanced CO tolerance in proton exchange membrane fuel cells by carbon supported PtMo alloy catalyst," Electrochemical and Solid-State Letters, vol. 2, no. 1, pp. 12-15, 1999.

[5] W. F. Lin, M. S. Zei, M. Eiswirth, G. Ertl, T. Iwasita, and W. Vielstich, "Electrocatalytic activity of Ru-modified Pt(111) electrodes toward CO oxidation," Journal of Physical Chemistry $B$, vol. 103, no. 33, pp. 6968-6977, 1999.
[6] W. Chrzanowski, H. Kim, and A. Wieckowski, "Enhancement in methanol oxidation by spontaneously deposited ruthenium on low-index platinum electrodes," Catalysis Letters, vol. 50, pp. 69-75, 1998.

[7] Y. Takasu, T. Kawaguchi, W. Sugimoto, and Y. Murakami, "Effects of the surface area of carbon support on the characteristics of highly-dispersed Pt-Ru particles as catalysts for methanol oxidation," Electrochimica Acta, vol. 48, no. 25-26, pp. 3861-3868, 2003.

[8] D. Shanna, K. Knights, M. Colbow, J. St-Pierre, and D. Wilkinson, "Aging mechanisms and lifetime of PEFC and DMFC," Journal of Power Sources, vol. 127, no. 1-2, pp. 127134, 2004.

[9] J. Wang and G. M. Swain, "Dimensionally stable Pt/diamond composite electrodes in concentrated $\mathrm{H} 3 \mathrm{PO} 4$ at high temperature," Electrochemical and Solid-State Letters, vol. 5, no. 2, pp. E4-E7, 2002.

[10] M. Hupert, A. Muck, J. Wang et al., "Conductive diamond thin-films in electrochemistry," Diamond and Related Materials, vol. 12, no. 10-11, pp. 1940-1949, 2003.

[11] C. H. Paik, T. D. Jarvi, and W. E. O’Grady, "Extent of PEMFC cathode surface oxidation by oxygen and water measured by CV," Electrochemical and Solid-State Letters, vol. 7, no. 4, pp. A82-A84, 2004.

[12] K. H. Kangasniemi, D. A. Condit, and T. D. Jarvi, "Characterization of vulcan electrochemically oxidized under simulated PEM fuel cell conditions," Journal of the Electrochemical Society, vol. 151, no. 4, pp. E125-E132, 2004.

[13] J. Wang, G. M. Swain, T. Tachibana, and K. Kobashi, "Incorporation of Pt particles in boron-doped diamond thin films. Applications in electrocatalysis," Electrochemical and SolidState Letters, vol. 3, no. 6, pp. 286-289, 2000.

[14] E. Antolinia, J. R. C. Salgado, R. M. da Silva, and E. R. Gonzalez, "Preparation of carbon supported binary Pt-M alloy catalysts $(\mathrm{M}=$ first row transition metals $)$ by low/medium temperature method," Materials Chemistry and Physics, vol. 101, no. 2-3, pp. 395-403, 2007.

[15] H. X. Huang, S. X. Chen, and C. Yuan, "Platinum nanoparticles supported on activated carbon fiber as catalyst for methanol oxidation," Journal of Power Sources, vol. 175, no. 1, pp. 166-174, 2008.

[16] G. Che, B. B. Lakshmi, E. R. Fisher, and C. R. Martin, "Carbon nanotubule membranes for electrochemical energy storage and production," Nature, vol. 393, no. 6683, pp. 346-349, 1998.

[17] Y. V. Pleskov, Y. E. Evstefeeva, M. D. Krotova et al., "Effect of crystal structure on the electrochemical behaviour of synthetic semiconductor diamond: comparison of growth and a nucleation surfaces of a coarse-grained polycrystalline film," Journal of Applied Electrochemistry, vol. 33, no. 10, pp. 909915, 2003.

[18] J. S. Gao, T. Arunagiri, J. J. Chen, P. Goodwill, and O. Chyan, "Preparation and characterization of metal nanoparticles on a diamond surface," Chemistry of Materials, vol. 12, no. 11, pp. 3495-3500, 2000.

[19] J. A. Bennett and G. M. Swain, "Investigating the nucleation and growth of electrodeposited Pt on polycrystalline diamond electrodes," Journal of the Electrochemical Society, vol. 157, no. 8, pp. F89-F95, 2010.

[20] Developed at the University of Texas Health Science Center at San Antonio, Tex, USA, and available from internet by anonymous FTP from, http://ddsdx.uthscsa.edu/dig/. 
[21] J. F. Moulder, W. F. Stickle, P. E. Sobol, and K. D. Bomben, Handbook of X-Ray Photoelectron Spectroscopy Perkin-Elmer Corporation, Perkin Elmer Corporation, Eden Praire, Minn, USA, 1992.

[22] A. Fujishima, Y. Einaga, T. Narasinga, and D. A. Tryk, Eds., Diamond Electrochemistry, Elsevier, Tokyo, Japan, 2005.

[23] F. Pruvost, E. Bustarret, and A. Deneuville, "Characteristics of homoepitaxial heavily boron-doped diamond films from their Raman spectra," Diamond and Related Materials, vol. 9, no. 3, pp. 295-299, 2000.

[24] N. Vinokur, B. Miller, Y. Avyigal, and R. Kalish, "Electrochemical behavior of boron-doped diamond electrodes," Journal of the Electrochemical Society, vol. 143, no. 10, pp. L238-L240, 1996.

[25] O. Enea, B. Riedo, and G. Dietler, "AFM study of Pt clusters electrochemically deposited onto Boron-doped diamond films," Nano Letters, vol. 2, no. 3, pp. 241-244, 2002.

[26] F. Montilla, E. Morallon, I. Duo, C. Comninellis, and J. L. Vazquez, "Platinum particles deposited on synthetic borondoped diamond surfaces. Application to methanol oxidatio," Electrochimica Acta, vol. 48, no. 25-26, pp. 3891-3897, 2003.

[27] J. A. Bennett, Y. Show, S. Wang, and G. M. Swain, "Pulsed galvanostatic deposition of Pt particles on microcrystalline and nanocrystalline diamond thin-film electrodes I. Characterization of as-deposited metal/diamond surfaces," Journal of the Electrochemical Society, vol. 152, no. 5, pp. E184-E192, 2005.

[28] R. Pattabiraman, "Electrochemical characterisation of platinum catalysts on carbon supports for fuel cell applications," Indian Journal of Chemical Technology, vol. 3, no. 5, pp. 269273, 1996

[29] A. M. Feltham and M. Spiro, "Platinized platinum electrodes," Chemical Reviews, vol. 71, no. 2, pp. 177-193, 1971.

[30] N. Tsubouchi, M. Ogura, H. Kato et al., "p-type doping by B ion implantation into diamond at elevated temperatures," Diamond and Related Materials, vol. 15, no. 1, pp. 157-159, 2006.

[31] P. John, N. Polwart, C. E. Troupe, and J. I. B. Wilson, "The oxidation of diamond: the geometry and stretching frequency of carbonyl on the (100) surface," Journal of the American Chemical Society, vol. 125, no. 22, pp. 6600-6601, 2003.

[32] C. D. Wagner, A. V. Naumkin, A. Kraut-Vass, J. W. Allison, C. J. Powell, and J. R. Rumble, "NIST X-Ray Photoelectron Spectroscopy Database, NIST Standard Reference Database 20," Version 3.4, (web version) U.S. Department of Commerce.

[33] T. Kondo, K. Honda, D. A. Tryk, and A. Fujishima, "Covalent modification of single-crystal diamond electrode surfaces," Journal of the Electrochemical Society, vol. 152, no. 1, pp. E18E23, 2005.

[34] I. Gonzalez-Gonzalez, E. R. Fachini, M. A. Scibioh et al., "Facet-selective platinum electrodeposition at free-standing polycrystalline boron-doped diamond films," Langmuir, vol. 25, no. 17, pp. 10329-10336, 2009.

[35] W. Chrzanowski and A. Wieckowski, "Surface structure effects in platinum/ruthenium methanol oxidation electrocatalysis," Langmuir, vol. 14, no. 8, pp. 1967-1970, 1998.

[36] H. A. Gasteiger, N. Marković, P. N. Ross, and E. J. Cairns, "Methanol electrooxidation on well-characterized Pt-Ru alloys," Journal of Physical Chemistry, vol. 97, no. 46, pp. 12020-12029, 1993.

[37] G. Siné and C. Comninellis, "Nafionß-assisted deposition of microemulsion-synthesized platinum nanoparticles on BDD: activation by electrogenerated $\cdot \mathrm{OH}$ radicals," Electrochimica Acta, vol. 50, no. 11, pp. 2249-2254, 2005.
[38] T. A. Enache, A. M. Chiorcea-Paquim, O. Fatibello-Filho, and A. M. Oliveira-Brett, "Hydroxyl radicals electrochemically generated in situ on a boron-doped diamond electrode," Electrochemistry Communications, vol. 11, no. 7, pp. 13421345, 2009.

[39] B. Marselli, J. Garcia-Gomez, P. A. Michaud, M. A. Rodrigo, and C. Comninellis, "Electrogeneration of hydroxyl radicals on boron-doped diamond electrodes," Journal of the Electrochemical Society, vol. 150, no. 3, pp. D79-D83, 2003.

[40] S. Desai and M. Neurock, "A first principles analysis of CO oxidation over Pt and Pt 66.7\%Ru33.3\% (111) surfaces," Electrochimica Acta, vol. 48, no. 25-26, pp. 3759-3773, 2003.

[41] J. A. Bennett, Y. Show, S. Wang, and G. M. Swain, "Preparation and characterization of boron-doped diamond powder-a possible dimensionally stable electrocatalyst support material," Journal of the Electrochemical Society, vol. 152, no. 5, pp. B369-B375, 2005. 


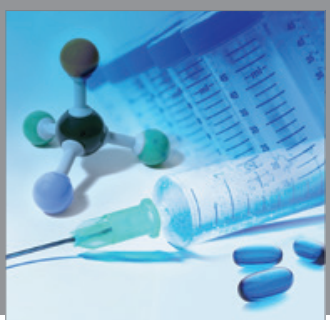

International Journal of

Medicinal Chemistry

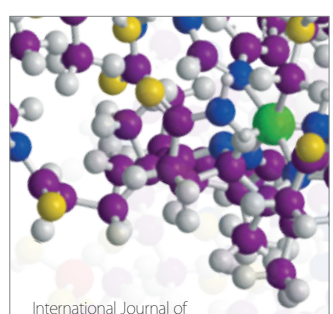

Carbohydrate Chemistry

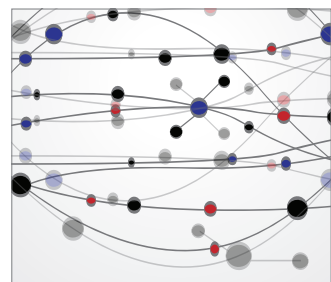

The Scientific World Journal
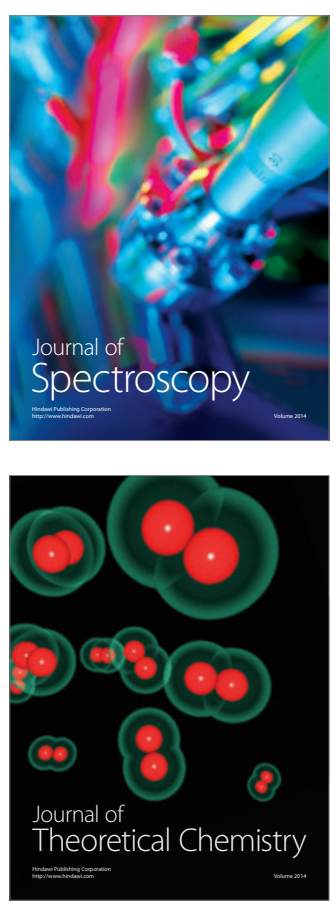
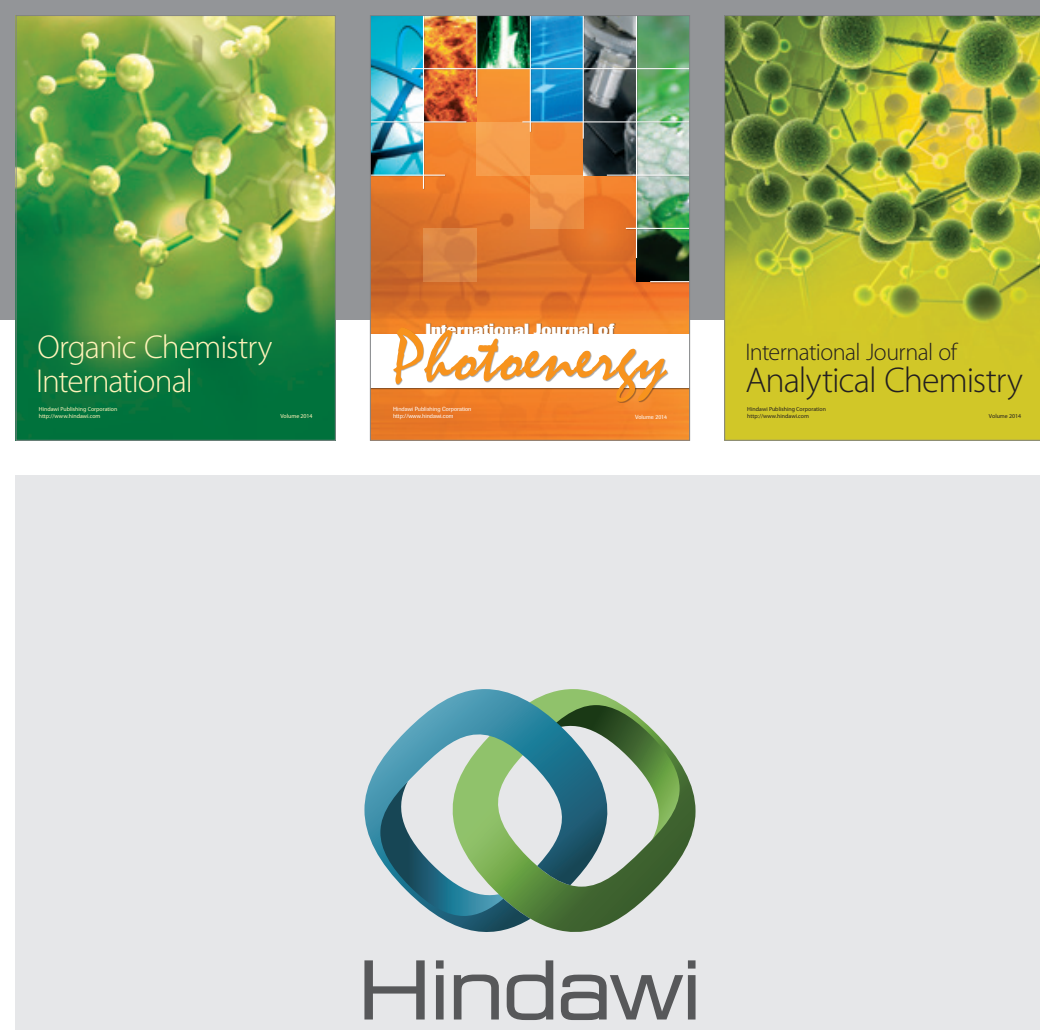

Submit your manuscripts at

http://www.hindawi.com
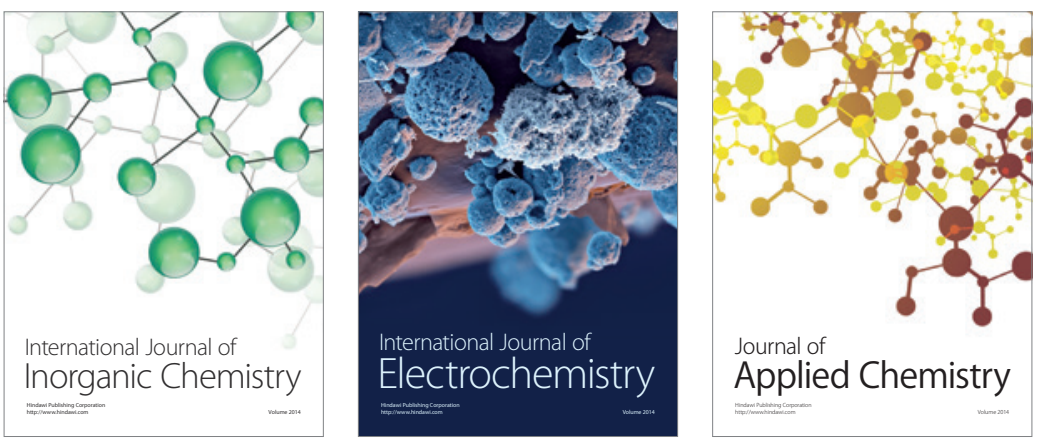

Journal of

Applied Chemistry
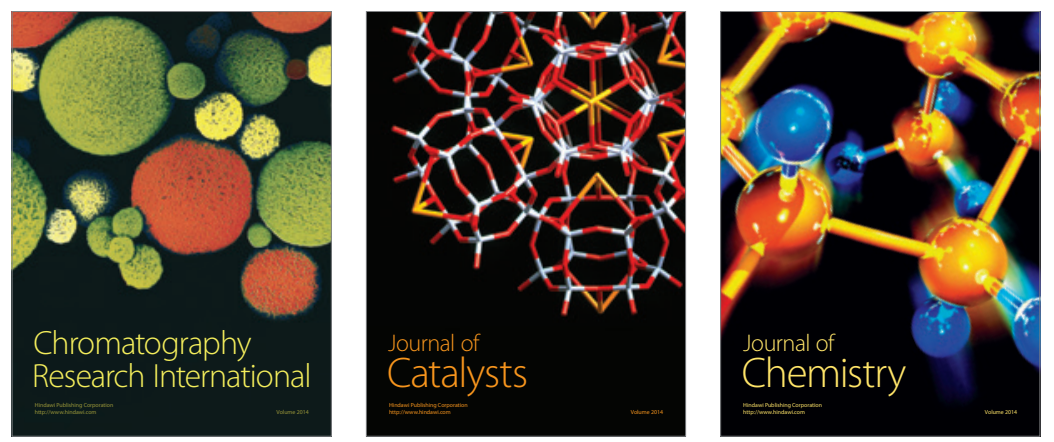
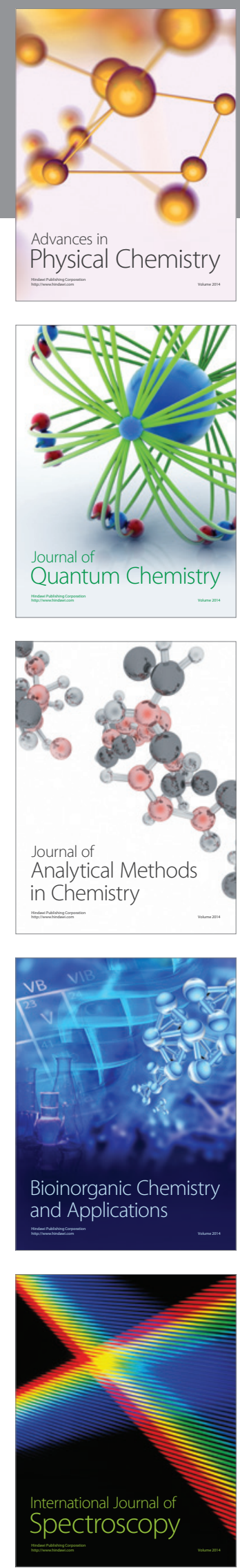